\title{
POTENSI KERJASAMA BILATERAL INDONESIA BANGLADESH DALAM KERANGKA PREFERENTIAL TRADE AGREEMENT
}

\author{
Deky Paryadi* \\ Pusat Pendidikan dan Pelatihan Perdagangan \\ ${ }^{*}$ Corresponding author \\ Email : deckyparyadi@gmail.com
}

\begin{abstract}
Abstrak
Saat ini Indonesia sedang melakukan inisiasi kerjasama perdagangan Indonesia Bangladesh PTA. Kerjasama perdagangan ini dalam rangka pengembangan produk eskpor Indonesia ke pasar non tradisional. Tujuan dari analisis ini adalah untuk Mengetahui kondisi perdagangan antara Indonesia dan Bangladesh serta mengetahui produk potensial Indonesia dipasar Bangladesh. Analisis ini menggunakan beberapa tools analisis seperti Trade Com plementarity Index, Revealed Symmetric Com parative Index serta analisis potensial produk. Dari hasil simulasi Trade Com plementarity Index (TCI), produk Indonesia selama 2 tahun terakhir (2017-2018), terlihat bahwa produk ekspor Indonesia dapat memenuhi keinginan pasar impor Bangladesh dan dapat diasumsikan masyarakat Bangladesh selama ini dapat menerima produk-produk dari Indonesia. Hasil RSCA antara Indonesia dan Bangladesh produk Indonesia memiliki daya saing secara relatif lebih tinggi dibanding produk Bangladesh pada sektor animal and animal product; vegetable products; foodstuffs; mineral products; plastics/rubber; wood and wood products; stone/glass; metals; machinery/electrical; transportations; dan miscellaneous. Dari hasil simulasi potensial produk, terdapat 283 pos tarif potensial yang dapat dijadikan indikasi request Indonesia dalam memulai kerjasama Indonesia Bangladesh PTA.
\end{abstract}

Kata kunci: Indonesia Bangladesh PTA, Trade ComplementarityIndex, Produk Potensial

\begin{abstract}
Currently, Indonesia is initiating trade cooperation between Indonesia and Bangladesh PTA. This trade cooperation is to increase Indonesia's exports to non-traditional markets. The purpose of this analysis is to determine the conditions of trade between Indonesia and Bangladesh and to find out Indonesia's potential products in the Bangladesh market. This analysis uses several analytical tools such as the Trade Com plementarity Index, Revealed Symmetric Com parative Index, and analysis of product potential. From the simulation results of the Trade Complementarity Index (TCI), Indonesian products for the last 2 years (2017-2018), it can be seen that Indonesian export products can meet the demands of the Bangladesh im port market and it can be assum ed that the people of Bangladesh have been able to receive products from Indonesia. The results of the RSCA between Indonesia and Bangladesh products, Indonesia have relatively higher com petitiveness com pared to Bangladesh in the sector of animal and animal product; vegetable products; foodstuffs; mineral products; plastics / rubber; wood and wood products; stone / glass; metals; machinery / electrical; transportations; and miscellaneous. From the simulation results of potential products, 283 tariff lines can be used as an indication of potential Indonesian request to initiate cooperation between Indonesia and Bangladesh PTA.
\end{abstract}

Keywords: Indonesia Bangladesh PTA, Trade Complementarity Index, Potential Products

(C) 2020 Pusdiklat Perdagangan. All rights reserv ed 


\section{PENDAHULUAN Latar Belakang}

Kawasan Asia Selatan merupakan salah merupakan kawasan potensial bagi pengembangan ekspor Indonesia. Indonesia telah lebih dulu melakukan kerjasama secara regional melalui ASEAN dengan India (Octaviani, 2009). Selain itu secara bilateral Indonesia Pakistan Preferential Ttrade Agreement (PTA) juga telah berjalan sejak tahun 2012 dan dimungkinkan akan melakukan peningkatan kerjasama kembali (Ditjen PPI Kemendag).

Saat ini Indonesia sedang gencar melakukan ekspansi ekspor ke negara tujuan non tradisional, salah satunya target kerjasama perdagangan Indonesia adalah dengan Bangladesh, karena dianggap sebagai negara potensial di kawasan Asia Selatan (Bisnis Indonesia, 2018).

Berdasarkan sumber primer yang diperoleh penulis dari Kementerian Perdagangan, hingga tahun 2018, Bangladesh merupakan salah satu negara di Asia Selatan yang belum melakukan perjanjian kerjasama perdagangan dengan Indonesia baik secara regional maupun bilateral. Hubungan perdagangan antara Indonesia dan Bangladesh sudah intensif sejak tahun 2004 yang ditandai dengan penandatanganan MoU on Comprehensive Trade and Economic Partnership antara Indonesia-Bangladesh. Pada KT IORA pada tahun 2017 kedua negara sepakat untuk membentuk Preferential Trade Agreement (PTA). Perundingan Indonesia Bangladesh PTA telah dimulai pada tahun 2019 dan hingga tulisan ini dibuat (November 2020) sudah memasuki perundingan ke 3 .

Pertumbuhan ekonomi Bangladesh sejak tahun 2011 ekonomi Bangladesh telah tumbuh di atas 6 persen pertahun (Kompas. Januari 2020). Berdasarkan perbandingan indikator ekonomi, pada tahun 2018, GDP Indonesia mencapai USD 1,02 triliun sementara Bangladesh hanya sebesar USD 287,1 miliar. Dengan jumlah populasi Indonesia di tahun yang sama sebanyak 264,16 juta jiwa, maka pendapatan perkapita penduduk Indonesia mencapai USD 3.870,56 per tahun. Sebaliknya, dengan jumlah populasi sejumlah 164,88 juta jiwa, pendapatan perkapita penduduk Bangladesh sebesar USD 1.744,51 per tahun. Pada tahun 2018, ingkat inflasi Bangladesh sedikit lebih tinggi yaitu $5,56 \%$ dibandingkan Indonesia yang sebesar 3,20 \% (IMF, 2020).

Tabel 1. Indicator Makroekonomi

\begin{tabular}{lcr}
\hline \multicolumn{1}{c}{$\begin{array}{c}\text { Indicator } \\
\text { Makroekonomi }\end{array}$} & Indonesia & \multicolumn{1}{c}{ Bangladesh } \\
\hline $\begin{array}{l}\text { GDP, current price } \\
\text { (USD Billion) }\end{array}$ & $1.022,45$ & 287,10 \\
$\begin{array}{l}\text { GDP percapita } \\
\text { (USD) }\end{array}$ & $3.870,56$ & $1.744,51$ \\
$\begin{array}{l}\text { Inflasi, av erage } \\
\text { consume price (\%) }\end{array}$ & 3,20 & 5,56 \\
$\begin{array}{l}\text { Populasi } \\
\text { (Juta) }\end{array}$ & 264,16 & 164,88 \\
\hline Sumber:IMF, 2020(diolah penulis) &
\end{tabular}

Sumber: IMF, 2020 (diolah penulis)

Perbandingan struktur komposisi GDP Indonesia dan Bangladesh dapat dilihat dari persentase pada beberapa sektor, antara lain jasa, industri dan pertanian Dari tiga sektor tersebut, Bangladesh secara umum ditopang oleh sektor pertanian dan jasa sebesar $42,8 \%$ dan $36,9 \%$ dari total GDP, sedangkan aktifitas sektor industri manufaktur Bangladesh hanya memberikan kontribusi terhadap GDP sebesar 20,5\%. Sementara itu di Indonesia, sektor jasa dan industri manufaktur berperan penting dalam perekonomian, yaitu sebesar $45,4 \%$ dan $41 \%$. Sementara untuk sektor pertanian memberikan kontribusi sebesar $13,6 \%$ dari GDP (CIA, 2017).

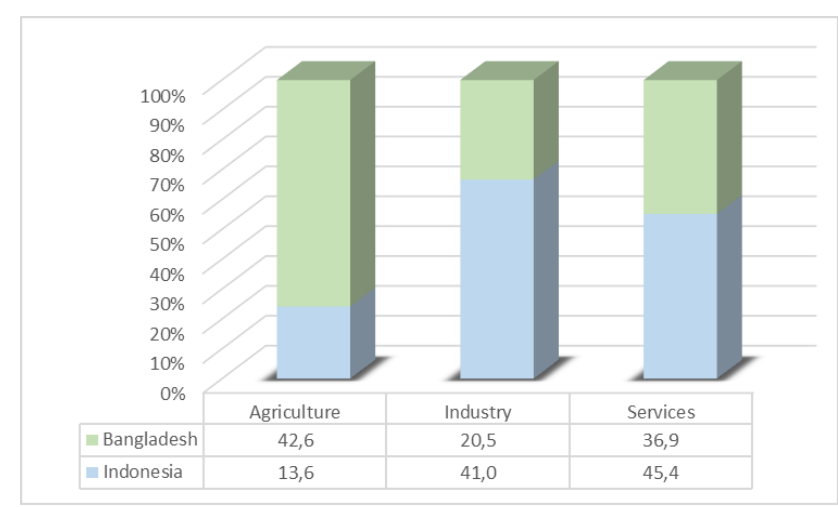

\section{Gambar 1. Komposisi GDP Indonesia dan Bangladesh (\%)}

Terkait pembentukan PTA antara Indonesia dan Bangladesh, yang saat ini masih dalam 
proses perundingan, maka penulis merasa perlu mengidentifikasi dan menganalisa indikator makroekonomi, hubungan dagang baik ekspor maupun impor, struktur tarif dan kelayakan kerjasama dimaksud. Analisis ini dilakukan sebagai bahan masukan bagi perundinga dalam memberikan pilihan request dan offer produk bagi Indonesia.

Adapun tujuan dari penelitian ini adalah untuk Mengetahui kondisi perdagangan antara Indonesia dan Bangladesh serta mengetahui produk potensial Indonesia dipasar Bangladesh.

\section{TINJAUAN PUSTAKA}

Teori perdagangan internasional dipelopori oleh Adam Smith dengan teorinya mengenai keunggulan absolut (absolute advantage). Teori keunggulan absolut menyatakan ketika suatu negara lebih efisien dibanding negara lain dalam memproduksi satu komoditi (komoditi tersebut disebut absolute advantage atau keunggulan absolute) tetapi tidak lebih efisien dalam memproduksi komoditi lain dibanding negara yang lainnya (absolute disadvantage) maka kedua negara tersebut dapat memperoleh keuntungan dari perdagangan dengan melakukan spesialisasi untuk memproduksi dan memperdagangkan komoditi yang memiliki keunggulan absolut tersebut (Salvatore, 2013).

David Ricardo menyempurnakan teori keunggulan absolut dari Adam Smith dengan mengenalkan teori keunggulan komparatif (comparative advantage). Teori tersebut menyatakan bahwa dalam keadaan free trade, apabila suatu negara kurang efisien dibandingkan negara lainnya dalam memproduksi kedua barang, kedua negara masih dimungkinkan untuk melakukan perdagangan yang menguntungkan kedua belah pihak. Negara yang pertama harus melakukan spesialisasi dalam produksi komoditas yang absolute disadvantagenya lebih kecil. komoditas inilah yang disebut sebagai keunggulan komparatif. Selain itu, negara tersebut harus mengimpor komoditas yang absolute disadvantagenya lebih besar, komoditas ini disebut sebagai ketidakunggulan komparatif (comparative disadvantage) (Salvatore, 2013).

Berbeda dengan teori Adam Smith dan Ricardian, Eli Heckscher dan Bertil Ohlin mengemukakan bahwa perbedaan keunggulan komparatif tercipta karena adanya perbedaan endowment. Perbedaan opportunity cost suatu produk antar negara dapat terjadi karena adanya perbedaan jumlah atau proporsi faktor produksi yang dimiliki (endowments factors) masing-masing negara. Perbedaan itulah yang mendorong terjadinya pertukaran barang antar negara. Teori tersebut menyatakan bahwa suatu negara akan cenderung mengekspor produk yang menggunakan secara intensif faktor produksi yang dimiliki relatif berlebih di negara tersebut dan mengimpor produk yang mengggunakan secara intensif factor produksi yang langka di negara tersebut. Berdasarkan model Hecksher-Ohlin ( $\mathrm{H}-\mathrm{O})$, perdagangan internasional mendorong suatu negara untuk menspesialisasikan industri dan perdagangannya pada barang yang secara intensif menggunakan faktor produksi yang berlebih di negara tersebut (Salvatore, 2013).

(Paryadi \& Salam, 2018) Penelitian bertujuan untuk mengetahui potensi daya saing komoditas serta dampak kerja sama perdagangan Indonesia-EAEU. Metode analisis yang digunakan adalah Trade Complementary Index (TCI), Revealed Symetric Comparative Advantages (RSCA) dan Computable General Equilibrium (CGE). Berdasarkan analisis $\mathrm{TCl}$, tingkat kesesuaian ekspor EAEU terhadap struktur impor Indonesia lebih tinggi dibandingkan ekspor Indonesia terhadap struktur impor EAEU. Sehingga Indonesia perlu menjajaki kemungkinan kerja sama dengan EAEU dengan pendekatan 
berupa eliminasi $50 \%$ pada seluruh pos tarif secara bertahap.

(Suharsih \& Sriwinarti, 2012) Upaya peningkatan daya saing industri produk ekspor merupakan salah satu tan-tangan yang harus dihadapi oleh Provinsi Yogyakarta dalam era Liberalisasi Perdagangan. Penelitian ini bertujuan mengetahui potensi dan daya saing produk ekspor Provinsi Yogyakarta. Sementara itu berdasarkan analisis Revealed Comparative Advantage (RCA) dan Indeks Spesialisasi, diketahui produk ekspor yang mempunyai prospek baik di masa datang dan berdaya saing tinggi adalah kulit dan barang dari kulit, kayu, barang dari kayu dan barang anyaman, serta tekstil dan barang dari tekstil.

(Ustriaji, 2017) Tujuan penelitian adalah untuk mengetahui tentang pertumbuhan, kontribusi serta daya saing dari komoditi unggulan Indonesia yang terdiri dari tekstil dan produk tekstil (TPT), elektronik, karet dan produk karet,sawit dan produk sawit, produk hasil hutan, alas kaki,otomotif, udang, kakao, dan kopi. Dari perhitungan RCA dapat menunjukkan bahwa industri tekstil dan produk tekstil pada tahun 2010- 2013 (RCA>1) artinya ekspor tersebut memiliki daya saing diatas daya saing rata-rata dunia. Daya saing tertinggi pada tahun 2010 dan 2011 dengan nilai 1,44. Namun komoditi tekstil dan produk tekstil 2010-2014 memiliki daya saing. Dari perhitungan RCA menunjukan bahwa industri sawit, hasil hutan, alas kaki, kakao, kopi, karet, dan tekstil pada tahun 2010-2014 memiliki daya saing diatas daya saing rata-rata dunia.

Keuntungan dari perdagangan (gain from trade) adalah keuntungan yang diperoleh suatu negara yang beralih dari kondisi autarky ke kondisi perdagangan bebas (Nordhaus, 2009). Teori perdagangan klasik menjelaskan bahwa perdagangan internasional yang bebas hambatan memungkinkan suatu negara untuk memperoleh barang yang diproduksi dengan biaya yang lebih rendah dibandingkan biaya produksi di dalam negeri. Hal tersebut karena masing-masing negara akan menspesialisasikan produksi dan perdagangannya pada barang yang memiliki keunggulan komparatif di negara tersebut. Keuntungan dari perdagangan bisa dibedakan menjadi "keuntungan konsumsi" yang diperoleh melalui pertukaran barang dan "keuntungan produksi" yang diperoleh melalui spesialisasi perdagangan (Sen, 2010).

Dalam teori perdagangan menyatakan bahwa perdagangan bebas berpotensi dapat mengurangi kendala bagi produsen di negara partisipan untuk memperoleh faktor produksi baik tenaga kerja, kapital, maupun sumber daya alam yang kurang tersedia di negara sendiri. Sehingga, konsumen dapat memperoleh barang yang lebih baik dan lebih beragam dari yang bisa disediakan di dalam negeri. Walaupun demikian, banyak negara menggunakan kebijakan perdagangan seperti tariff dan non-tariff untuk menghambat perdagangan. Alasan utama pemberlakuan tarif adalah sebagai proteksi industri dalam negeri dan beberapa negara juga menggunakan tarif sebagai sumber pendapatan pemerintah. Selain tarif, instrument lain yang digunakan untuk menghambat perdagangan adalah kebijakan non tarif atau lebih dikenal dengan Non tariff Measures (NTM), diantaranya adalah quota, dumping, standard dan isu non ekonomi seperti kesehatan dan keamanan. Walaupun tarif bersifat lebih transparan diantara instrumen kebijakan lainnya, namun tarif sangat mempengaruhi aliran perdagangan serta berdampak pada kesejahteraan perekonomian (Sen, 2010).

\section{METODE PENELITIAN}

Analisis potensi kerjasama perdagangan antara Indonesia dan Bangladesh akan dilakukan dengan pendekatan kuantitatif. Pendekatan kuantitatif ini akan memaparkan kinerja perdagangan kedua belah pihak menggunakan beberapa tools analisis seperti Trade Complementarity Index, Revealed Symmetric Comparative Index serta analisis produk potensial. Analisis Potensi produk akan 
dilihat dan dihitung menggunakan data ekspor impor Indonesia dan Bangladesh.

\section{Kesesuaian Struktur Perdagangan (Trade Complementarity)}

Salah satu tools, untuk melihat tingkat kecocokan struktur impor dan ekspor suatu negara adalah dengan menggunakan Trade Complementary Index (TCl). Alat analisis ini untuk mengukur tingkat komplementaritas perdagangan yang ada antara kedua negara (Khadan \& Hosein, 2016). Trade Complementarity Index ini untuk menunjukkan apakah dua negara mitra adalah negara yang saling melengkapi dalam perdagangan atau merupakan negara yang saling bersaing. Makin tinggi indek $\mathrm{TCl}$ maka dapat diasumsikan ekspor negara tersebut makin dapat melengkapi kebutuhan impor negara lainnya. Dua negara dikatakan saling melengkapi jika masing-masing memiliki struktur Perdagangan yang berbeda. Artinya impor negara yang satu merupakan ekspor negara yang lain dan sebaliknya. Namun jika kedua negara memiliki struktur ekspor yang sama maka negara tersebut disebut saling bersaing

$\mathrm{TCl}$ dapat dirumuskan sebagai berikut:

$T C I_{i j}=100-\sum_{k=1}^{n} \frac{\left|m_{j}^{k}-x_{i}^{k}\right|}{2}$

Di mana $x_{i}^{k}$ adalah share ekspor negara i untuk produk $k$ terhadap total ekspor negara tersebut. Sedangkan adalah $m_{j}^{k}$ share impor negara j untuk produk $k$ yang sama terhadap total impor negara j. Indeks TCl dihitung dari tahun 2009 hingga 2012 sesuai dengan ketersediaan data untuk kedua negara dan kalkulasi indeks tersebut didasarkan pada level HS 6 dijit yang bersumber dari UN Comtrade (Paryadi, 2019).

\section{Revealed Symmetric Comparative Advantage (RSCA)}

Metodologi yang sebelumnya diperkenalkan oleh (Dalum, 2010) ini merevisi sifat simetris dari Revealed Comparative Advantage (RCA). Indeks RCA Balassa pada dasarnya mengukur pangsa (share) ekspor suatu negara yang dinormalkan dengan ekspor pada industri atau produk yang sama dalam satu kelompok negara (Anggoro \& Widyastutik, 2016) . RSCA mempunyai jangkauan berkisar dari minus satu sampai satu. Distribusi RSCA dapat digunakan untuk menganalisa dinamisasi dari keunggulan komparatif. Kecenderungan nilai positif dari koefisien RSCA untuk negara tertentu pada tahun tertentu menunjukkan bahwa negara tersebut lebih terkonsentrasi pada produk yang memiliku keunggulan komparatif yang rendah. Sebaliknya, apabila kecenderungan koefisien RSCA nya negatif, maka negara tersebut terkonsentrasi lebih banyak pada prduk yang memiliki keunggulan komparatif yang tinggi (Laursen, 2015).

Karena indeks tidak dapat dibandingkan secara bersamaan pada kedua sisi, RCA dimodifikasi menggunakan persamaan berikut

$$
R S C A=\frac{R C A-1}{R C A+1}
$$

Nilai-nilai RSCA lebih besar dari satu (dan unbounded) didefinisikan sebagai adanya spesialisasi, dan apabila nilai kurang dari satu (dan dibatasi oleh nol) berarti tidak adanya spesialisasi.

\section{Potensial Product}

Analisis potensial produk ini penting digunakan untuk memperkuat analisa daya saing produk. Analisa ini menggunakan data yang lebih update dengan melihat ekspor dan impor kedua negara dalam waktu yang bersamaan. Analisa potensial produk untuk request Indonesia ini akan disimulasikan dengan menggunakan data base tarif Bangladesh serta data-data sekunder yang diperoleh melalui data ekspor impor Indonesia dan Bangladesh. Simulasi ini dibuat dengan mempertimbangkan beberapa indikator, yaitu:

- Tarif Bea Masuk Bangladesh

- Impor Bangladesh dari Indonesia / Ekspor Indonesia ke Bangladesh

- Ekspor Indonesia ke Dunia

- Impor Bangladesh dari Dunia 


\section{PEMBAHASAN}

\section{Kinerja Ekspor Impor Indonesia dan Bangladesh}

Saat ini kinerja perdagangan IndonesiaBangladesh selama periode tahun 2015-2020 mengalami trend peningkatan rata-rata $11,8 \%$ per tahun. Pada tahun 2019 total perdagangan Indonesia dengan Bangladesh mencapai USD 2 miliar. Dari sisi kinerja ekspor Indonesia ke Bangladesh terjadi peningkatan rata-rata $11,8 \%$ per tahun selama periode 2015-2019. Sementara dari sisi impor, dalam periode 2015-2019, impor Indonesia dari Bangladesh meningkat rata-rata $13,1 \%$ per tahun. Dengan demikian, neraca perdagangan Indonesia dengan Bangladesh berhasil mencatatkan surplus bagi Indonesia dengan rata-rata peningkatan sebesar 11,7\% per tahun selama tahun 2015-2019 (BPS, 2020) (tabel 1 lampiran)

Pada tahun 2018, Bangladesh merupakan negara tujuan ekspor Indonesia peringkat ke19 dengan nilai ekpor sebesar USD 1,9 miliar. Nilai pangsa ekspor Indonesia ke Bangladesh mencapai 1,05\% dari total ekspor Indonesia ke dunia pada tahun 2018. Dalam kurun waktu 2014-2018 angka pertumbuhan ekspor Indonesia ke Bangladesh mencapai 8,38\% per tahun (BPS, 2020).

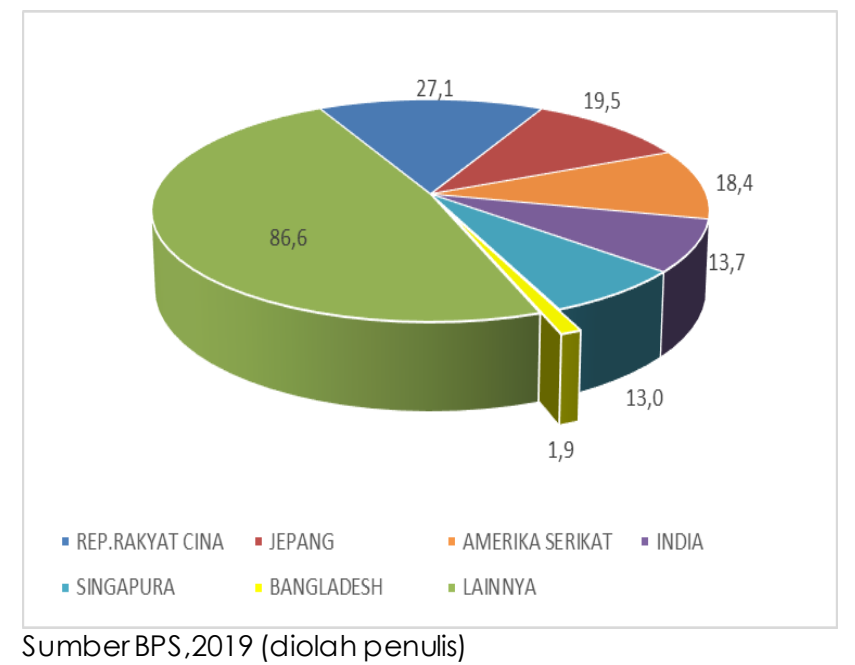

\section{Gambar 2. Posisi Bangladesh Sebagai Negara Tujuan Ekspor Indonesia (Miliar USD)}

Nilai ekspor Indonesia ke Bangladesh pada tahun 2018 adalah USD 1,9 miliar. Pada tahun 2018, 20 besar produk ekspor Indonesia ke Bangladesh adalah senilai USD 1,6 miliar atau setara dengan $84,86 \%$ dari total ekspor Indonesia ke Bangladesh. Produk ekspor utama Indonesia pada tahun 2018 didominasi oleh kelapa sawit dengan nilai ekspor sebesar USD 840,1 ribu. Produk ekspor lainnya adalah produk pulp kayu, minyak bumi atau mineral bitumen, batu bara, semen, dan lainnya (BPS, 2020).

Pada tahun 2018, Bangladesh merupakan negara asal impor Indonesia peringkat 67 dengan nilai impor sebesar USD 89,5 juta. Nilai pangsa impor Indonesia dari Bangladesh masih pada kisaran 0,05\% dari total impor Indonesia dari dunia pada tahun 2018. Dalam kurun waktu 2014-2018 angka pertumbuhan impor Indonesia dari Bangladesh mencapai 6,84\% per tahun. (BPS, 2020)

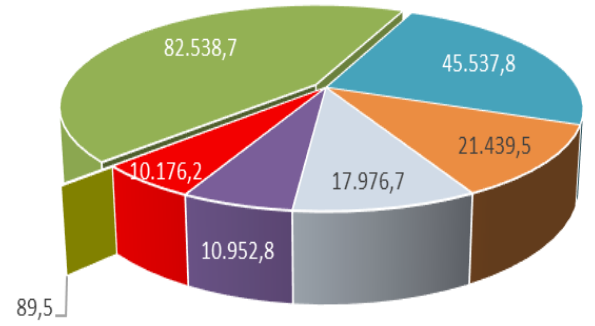

$$
\begin{aligned}
& \text { " REP.RAKYAT CINA " SINGAPURA " JEPANG " THAILAND } \\
& \text { - AMERIKA SERIKAT " BANGLADESH }
\end{aligned}
$$

Sumber BPS,2019 (diolah penulis)

\section{Gambar 3. Posisi Bangladesh Sebagai Negara Asal Impor Indonesia (Juta USD)}

Sebagai perbandingan dapat dilihat realisasi ekspor Indonesia ke negara dikawasan Asia Selatan (ITC TradeMap, 2019). Bangladesh merupakan pangsa ekspor ke-3 Indonesia di Asia Selatan setelah India dan Pakistan. Sebagaimana kita ketahui India dan pakistan telah memiliki kerjasama dengan Indonesia sebelumnya. Kerjasama Indonesia dengan India melalui skema Regional yaitu ASEAN - 
India FTA sedangkan kerjasama antara Indonesia dengan Pakistan melalui kerjasama Bilateral yaitu Indonesia - Pakistan Preferential Trade Agreement.

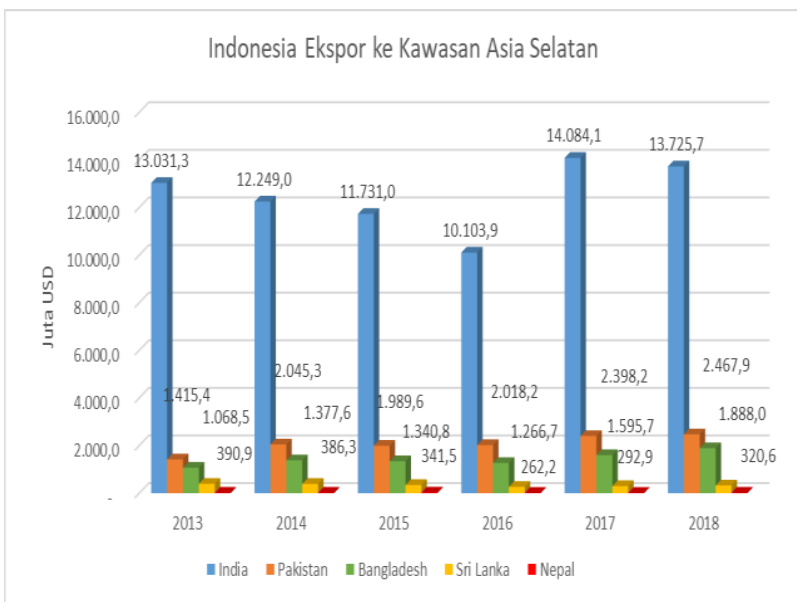

Sumber TradeMap, 2019 (diolah penulis)

\section{Gambar 4. Posisi Bangladesh Sebagai Negara Tujuan Ekspor Indonesia (Juta USD)}

\section{Tarif Bea Masuk Bangladesh}

Dari 6738 Pos Tarif yang ada, Bangladesh masih memiliki struktur tariff bea masuk yang bervariasi. Kisaran besaran tarif Most Favoured Nation (MFN) berada diantara 0\% hingga 25\%, sementara Bangladesh juga menerapkan tariff bea masuk spesifik. Tarif $0 \%$ dikenakan untuk 312 Pos Tarif atau 4,6\% dari seluruh produk Bangladesh. Sementara tarif bea masuk di kisaran $0<\mathrm{X}<5$ sebanyak 1745 Pos Tarif. Sekitar 3077 Pos Tarif Bangladesh masih mengenakan tariff bea masuk yang tinggi yatu di kisarana 10 $<X<77$ atau sekitar $45,7 \%$ dari jumlah total pos tariff. Bangladesh juga menerapkan tarif campuran (tarif ad valorem + tarif spesifik untuk 44 pos tariff.

Tabel 2. Struktur Tarif Bangladesh

\begin{tabular}{lrr}
\hline \multicolumn{1}{c}{$\begin{array}{c}\text { Tarif Bea } \\
\text { Masuk }\end{array}$} & $\begin{array}{c}\text { Jumlah } \\
\text { Pos Tarif }\end{array}$ & \% Jumlah Produk \\
\hline 0 & 312 & 4,6 \\
$0<X \leq 5$ & 1745 & 25,9 \\
$5<X \leq 10$ & 1560 & 23,2 \\
$10<X \leq 25$ & 3077 & 45,7 \\
$X>25$ & 44 & 0,7 \\
\hline
\end{tabular}

\begin{tabular}{lll}
\hline Total & 6738 & 100,0
\end{tabular}

Sumber: Direktorat Bilateral Kemendag, (diolah penulis)

\section{Analisis Kelayakan Kerjasama}

\section{Trade Complementary Index / TCl}

Trade Complementary Index (TCI) antara Indonesia dan Bangladesh dapat memberikan informasi yang berguna bagi prospek perdagangan intra-regional. Hal ini menunjukkan tingkat kecocokan struktur impor dan ekspor suatu negara. TCl merupakan salah satu alat analisis dalam mempertimbangkan pembentukan kerjasama perdagangan dengan negara mitra.

Berdasarkan hasil penghitungan indek, tingkat complementary Indonesia lebih tinggi dibandingkan Bangladesh. Dari nilai indikator TCl tahun 2018 dapat dikatakan bahwa tingkat kesesuaian struktur ekspor Indonesia terhadap struktur impor Bangladesh adalah 20,1\% sementara kesesuaian struktur ekspor Bangladesh terhadap struktur impor Indonesia adalah 3,0\%. Hal ini menunjukkan bahwa Indonesia memiliki kemampuan memenuhi permintaan impor Bangladesh lebih baik dibandingkan Bangladesh memenuhi impor Indonesia (Juventia et al., 2019) .

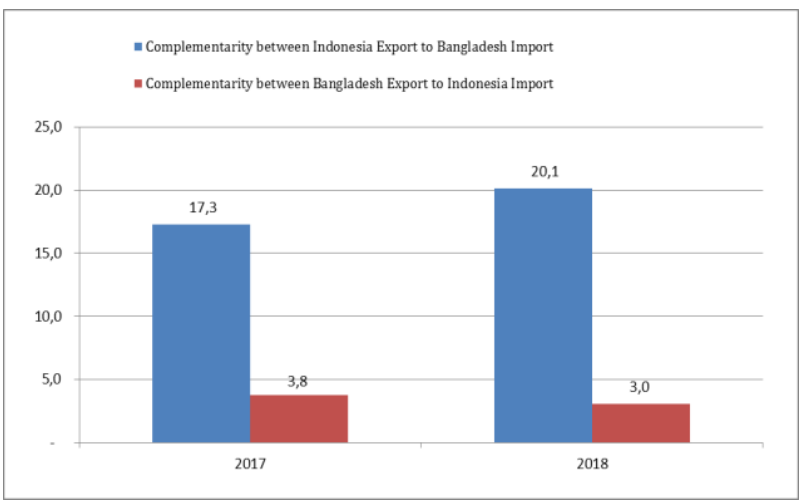

Gambar 5. Trade Complementary Index

\section{Competitiveness Index / Revealed Symmetric Comparative Advantage (RSCA)}

RSCA bilateral antara Indonesia dan Bangladesh menunjukkan bahwa produk Indonesia memiliki daya saing secara relatif lebih tinggi di dibanding Bangladesh pada 
sektor animal and animal product; vegetable products; foodstuffs; mineral products; plastics/rubber; wood and wood products; stone/glass; metals; machinery/electrical; transportations; dan miscellaneous. Sedangkan Bangladesh memiliki daya saing di relatif lebih tinggi dibandingkan Indonesia untuk sektor raw hides, skins, leather and furs; textile; footwear; metals; machinery; dan transportation.

Tabel 3. Bilateral Revealed Symmetric Comparative Advantage

\begin{tabular}{|c|c|c|c|c|}
\hline \multirow{2}{*}{ ctor } & \multicolumn{2}{|c|}{$\begin{array}{l}\text { RSCA Indonesia } \\
\text { Relative to }\end{array}$} & \multicolumn{2}{|c|}{$\begin{array}{l}\text { RSCA Bangladesh } \\
\text { Relative to }\end{array}$} \\
\hline & Bangladesh & Global & Indonesia & Global \\
\hline $\begin{array}{l}\text { animal and animal } \\
\text { product }\end{array}$ & 0,25 & 0,08 & $-0,25$ & $-0,17$ \\
\hline vegetable products & 0,97 & 0,62 & $-0,97$ & $-0,87$ \\
\hline foodstuffs & 0,79 & 0,13 & $-0,79$ & $-0,74$ \\
\hline mineral products & 0,99 & 0,30 & $-0,99$ & $-0,99$ \\
\hline $\begin{array}{l}\text { chemical and allied } \\
\text { industries }\end{array}$ & 0,93 & $-0,14$ & $-0,93$ & $-0,95$ \\
\hline plastics/rubber & 0,90 & 0,06 & $-0,90$ & $-0,89$ \\
\hline $\begin{array}{l}\text { raw hides, skins, } \\
\text { leather and furs }\end{array}$ & $-0,48$ & $-0,23$ & 0,48 & 0,29 \\
\hline $\begin{array}{l}\text { wood and wooden } \\
\text { products }\end{array}$ & 0,96 & 0,50 & $-0,96$ & $-0,87$ \\
\hline textile & $-0,85$ & 0,26 & 0,85 & 0,91 \\
\hline footwear/headgear & $-0,01$ & 0,55 & 0,01 & 0,55 \\
\hline stone/glass & 0,92 & $-0,06$ & $-0,92$ & $-0,93$ \\
\hline metals & 0,92 & $-0,30$ & $-0,92$ & $-0,95$ \\
\hline machinery/electrical & 0,94 & $-0,50$ & $-0,94$ & $-0,98$ \\
\hline transportation & 0,80 & $-0,46$ & $-0,80$ & $-0,92$ \\
\hline miscellaneous & 0,51 & $-0,53$ & $-0,51$ & $-0,82$ \\
\hline \multicolumn{5}{|l|}{ Explanatory Note } \\
\hline $\begin{array}{l}\text { Maximum Value of } \\
\text { RSCA }\end{array}$ & 1,00 & & & \\
\hline $\begin{array}{l}\text { Minimum Value of } \\
\text { RSCA }\end{array}$ & $-1,00$ & & & \\
\hline Critical Point & $\begin{array}{l}\text { Compar } \\
\text { Advanta }\end{array}$ & & & \\
\hline
\end{tabular}

\section{Produk Potensial Request Indonesia}

\section{Request Produk Potensial Indonesia yang memiliki nilai Export}

Dari hasil simulasi diperoleh bahwa terdapat sekitar 115 pos tarif Bangladesh yang terdapat existing trade atau sudah memiliki nilai perdagangan dengan Indonesia, sehingga potensial dapat dijadikan request indonesia.

Dari 115 pos tarif tersebut diurutkan berdasarkan import Bangladesh dari dunia, sehingga dapat diasumsikan Bangladesh merupakan market yang besar. Kemudian dilihat bea masuk dari pos tarif tersebut, apabila masih tinggi yaitu 5-25 maka dapat diasumsikan Indonesia akan meminta untuk dilakukan tariff eliminasi atau tariff reduction. Dari 115 pos tarif potesial tersebut terdiri dari beberapa pos tarif yang mewakili beberapa sektor produk antara lain: 15 pos taris sektor ESDM, 38 pos tarif sektor pertanian, 55 pos tarif sektor industri, 6 pos tarif sektor kehutanan dan 1 pos tarif sektor perikanan.

Produk-produk request potensial ini, dapat menjadi trigger untuk mendorong nilai perdagangan Indonesia yang masih rendah ke Bangladesh. Sehingga existing export trade yang sudah ada selama ini antara Indonesia dengan Bagladesh dapat terus ditingkatkan.

\section{Request Produk Potensial Indonesia yang belum memiliki nilai export}

Dari hasil simulasi, juga diperoleh produk potensial yang berasal dari produk yang non existing trade atau ekspor Indonesia yang belum ada namun Bangladesh melakukan importasi yang banyak dari dunia. Dari hasil simulasi tersebut terdapat 168 pos tarif potensial yang dapat di request Indonesia dalam kerjasama Indonesia Bangladesh PTA. Dari 168 pos tanif tersebut terdiri dari beberapa sektor produk, antara lain : 84 pos tarif sektor industri, 39 pos tarif sektor ESDM, 22 pos tarif sektor perikanan, 16 pos tarif sektor pertanian, 6 pos tarif sektor kehutanan, dan 1 pos tarif sektor kesehatan.

Dari hasil simulasi potensial produk. terdapat 283 pos tarif potensial yang berasal dari 115 Pos tarif existing trade dan 168 pos tarif non existing trade. Semua pos tarif yang di request diasumsikan oleh penulis akan dilakukan eliminasi tarif hingga $0 \%$ dari masing-masing base tariff. Adanya eliminasi tarif dari 283 pos tarif yang di request oleh Indonesia ini ini diharapkan dapat meningkatkan ekspor 
Indonesia ke Bangldesh yang sebelumnya terdapat hambatan tarif yang dapat mengurangi daya saing produk Indonesia di Bangladesh karena bea masuk yang besar.

\section{KESIMPULAN}

Dari hasil simulasi $\mathrm{TCl}$, produk Indonesia selama 2 tahun terakhir (2017-2018), terlihat bahwa produk ekspor Indonesia dapat memenuhi keinginan pasar impor Bangladesh dan dapat diasumsikan masyarakat Bangladesh selama ini dapat menerima produk-produk dari Indonesia.

Hasil RSCA bilateral antara Indonesia dan Bangladesh menunjukkan bahwa produk Indonesia memiliki daya saing secara relatif lebih tinggi di dibanding Bangladesh pada sektor animal and animal product; vegetable products; foodstuffs; mineral products; plastics/rubber; wood and wood products; stone/glass; metals; machinery/electrical; transportations; dan miscellaneous.

Dari hasil simulasi potensial produk, terdapat 283 pos tarif potensial yang berasal dari 115 Pos tarif existing trade dan 168 pos tarif non existing trade. Untuk dapat meningkatkan daya saing produk Indonesia, maka dalam kerjasama Indonesia Bangladesh PTA ini Indonesia dapat meminta eliminasi / reduksi tarif bea masuk untuk produk-produk yang masih memiliki bea masuk yang tinggi. Request produk potensial ini dapat dilihat dari produk yang sudah memiliki nilai perdagangan (existing trade) dan produk yang belum memiliki nilai perdagangan (non existing trade) tapi Bangladesh memiliki nilai impor yang besar dari Rest of the World.

Melihat arah kebijakan Pemerintah yang menyasarkan kepada pasar non tradisional, maka Bangladesh dapat menjadi pasar baru bagi pengembangan ekspor produk-produk Indonesia. Dengan membandingkan indikator makro antara Indonesia dan Bangladesh.

\section{DAFTAR PUSTAKA}

Bisnis Indonesia. (2018). https://ekonomi.bisnis.com/read/2018020 5/12/734581/perjanjian-dagang-potensi- asia-selatan-ini-kata-kadin

Anggoro, R., \& Widyastutik, W. (2016). Non-Tariff Barriers and Factors that influence The Indonesian Cocoa Export to Europe. Signifikan: Jurnal Ilmu Ekonomi. https://doi.org/10.15408/sjie.v5i1.3131

BPS. (2020). Perkembangan Ekspor dan Impor Indonesia Mei 2020. Badan Pusat Statistik.

CIA. (2017). The World Factbook - Central Intelligence Agency. In World Factbook. https://www.cia.gov/library/publications/t he-world-factbook/geos/rp.html

Dalum, B. (2010). Export specialisation, structural competitiveness and national systems of innovation. In National Systems of Innovation: Toward a Theory of Innovation and Interactive Learning. https://doi.org/10.7135/UPO978184331890 3.011

IMF. (2020). World Economic Outlook, June 2020. World Economic Outlook Update.

ITC TradeMap. (2019). Estadísticas del comercio para el desarrollo internacional de las empresas. Datos anuales [Base de datos]. ITC Trade Map.

Juventia, D. C., Choirulina, E., \& Anggrainy, Y. A. (2019). The Economic Impact of Indonesia-Bangladesh Preferential Trade Agreement. https://doi.org/10.2991/icot19.2019.8

Khadan, J., \& Hosein, R. (2016). Trade, Economic and Welfare Impacts of the CARICOM-Canada Free Trade Agreement.

Laursen, K. (2015). Revealed comparative advantage and the alternatives as measures of international specialization. Eurasian Business Review, 5(1), 99-115. https://doi.org/10.1007/s40821-015-0017-1

Nordhaus, W. D. (2009). Paul Samuelson and Global Public Goods. In Samuelsonian Economics and the Twenty-First Century. https://doi.org/10.1093/acprof:oso/978019 9298839.003.0006

Octaviani, I. (2009). Hubungan Kerjasama Perdagangan Internasional Antara RI- 
India Dalam Impor Cpo Asal Indonesia 2006-2009 Indah Octaviani Pembimbing: Indra Pahlawan Sip, Msi. Hubungan Kerjasama Perdagangan Internasional Antara RI-India Dalam Impor CPO Asal Indonesia 2006-2009.

Paryadi, D. (2019). Dampak Kerja Sama Perdagangan Indonesia dengan Negara Gulf Cooperation Council (GCC). Kajian Ekonomi Dan Keuangan. https://doi.org/10.31685/kek.v2i3.378

Paryadi, D., \& Salam, A. R. (2018). DAMPAK KERJA SAMA PERDAGANGAN INDONESIA DENGAN EURASIAN ECONOMIC UNION (EAEU) TERHADAP PEREKONOMIAN INDONESIA. Buletin IImiah Litbang Perdagangan. https://doi.org/10.30908/bilp.v12i2.320

Salvatore, D. (2013). International Economics. In Review of International Political Economy. https://doi.org/10.4324/9780203462041

Sen, S. (2010). International Trade Theory and Policy: A Review of the Literature. SSRN Electronic Journal, November 2010. https://doi.org/10.2139/ssrn.1713843

Suharsih, S., \& Sriwinarti, A. (2012). Daya Saing Produk Ekspor Di Era Perdagangan Bebas. Jurnal Ekonomi Dan Studi Pembangunan.

Ustriaji, F. (2017). ANALISIS DAYA SAING KOMODITI EKSPOR UNGGULAN INDONESIA DI PASAR INTERNASIONAL. Jurnal Ekonomi Pembangunan. https://doi.org/10.22219/jep.v14i2.3851 
Lampiran

Tabel 4. Neraca Perdagangan Indonesia-Bangladesh

\begin{tabular}{|c|c|c|c|c|c|c|}
\hline \multirow{2}{*}{ Uraian } & \multicolumn{5}{|c|}{ Nilai : USD Juta } & \multirow{2}{*}{$\begin{array}{c}\text { Trend } \\
(\%) \\
15-19\end{array}$} \\
\hline & 2015 & 2016 & 2017 & 2018 & 2019 & \\
\hline Total Perdagangan & $1.400,3$ & $1.335,1$ & $1.668,9$ & $1.979,7$ & $2.009,9$ & 11,8 \\
\hline Migas & 2,4 & 6,8 & 16,1 & 150,5 & 101,2 & 476,5 \\
\hline Non Migas & $1.400,0$ & $1.334,4$ & $1.652,8$ & $1.829,2$ & $1.908,7$ & 9,8 \\
\hline Ekspor & $1.340,8$ & $1.266,7$ & $1.595,7$ & $1.890,3$ & $1.913,8$ & 11,8 \\
\hline Migas & 2,4 & 6,8 & 16,1 & 150,5 & 101,2 & 476,5 \\
\hline Non Migas & $1.340,6$ & $1.266,0$ & $1.579,6$ & $1.739,8$ & $1.812,5$ & 9,7 \\
\hline Impor & 59,5 & 68,4 & 73,1 & 89,5 & 96,1 & 13,1 \\
\hline Migas & & & & & 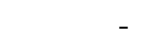 & 0,0 \\
\hline Non Migas & 59,5 & 68,4 & 73,1 & 89,5 & 96,1 & 13,1 \\
\hline Neraca & $1.281,3$ & $1.198,3$ & $1.522,6$ & $1.800,8$ & $1.817,7$ & 11,7 \\
\hline Migas & 2,4 & 6,8 & 16,1 & 150,5 & 101,2 & 476,5 \\
\hline Non Migas & $1.281,1$ & $1.197,6$ & $1.506,5$ & $1.650,3$ & $1.716,4$ & 9,5 \\
\hline
\end{tabular}

Tabel 5 Jumlah Pos Tarif Initial Request Indonesia

\begin{tabular}{lrrr}
\hline $\begin{array}{c}\text { Tarif Bea Masuk } \\
\text { Bangladesh (\%) }\end{array}$ & Pos Tarif & $\begin{array}{c}\text { Impor Bangladesh dari } \\
\text { Indonesia (USD Ribu) }\end{array}$ & \multicolumn{1}{c}{$\begin{array}{c}\text { Impor Bangladesh dari } \\
\text { Dunia (USD Ribu) }\end{array}$} \\
\hline 5 & 59 & $35.250,0$ & $2.171 .788,4$ \\
10 & 69 & $222.753,0$ & $3.178 .901,1$ \\
15 & 8 & 34,8 & $56.836,2$ \\
25 & 144 & $26.328,0$ & $747.665,7$ \\
Tarif Spesifik & 3 & 29,0 & $355.692,3$ \\
\hline Total & 283 & $284.394,8$ & $6.510 .883,6$ \\
\hline
\end{tabular}

Sumber Direktorat Kerjasama Bilateral PPI Kemendag, 2020 (diolah penulis) 